\title{
Use of NIH funds placed under a spotlight
}

\section{WASHINGTON DC}

Congressman Joe Barton wants to know whether biomedical researchers funded by the US National Institutes of Health $(\mathrm{NIH})$ are spending their grants haphazardly - overpaying research assistants, for example, or winning funds for phantom projects that they then use to do other research.

Barton, a Republican representative for Texas, heads the committee in the House of Representatives that oversees the NIH. After the committee's investigation of conflicts of interest inside the agency, revised ethics rules made their debut last month. Now the focus is on scientists outside the agency, at research hospitals and universities, who work with NIH funds.

After reading a 16 August article in the Wall Street Journal about a whistle-blower at
Cornell University's medical school in New York, and after receiving direct complaints, Barton's office sent two letters to Daniel Levinson, the inspector-general at the NIH's parent department, Health and Human Services.

One letter asks for a broad investigation into large grants to dinical-research centres, which can be worth many millions of dollars and cover many activities. The second
"These are grants, not contracts. There's a certain amount of discretion." based on complaints the committe received saying that some graduate assistants at the University of California, Davis, receive salaries and tuition waivers that amount to six times the salary of a postdoc.

Chris Harrington, director of communica- tions in the University of California's federalrelations office, says he believes that the university complies with federal law.

And Norka Ruiz Bravo, deputy director for extramural research at the NIH, says she would be happy to cooperate with an investigation, but is not convinced there is a problem. ${ }^{\alpha}$ We're careful stewards of taxpayer funds. I would be surprised if there is widespread misuse of them," she said.

${ }^{\alpha}$ You have to remember that these are grants, not contracts, ${ }^{p}$ she adds. ${ }^{\alpha}$ There is a certain amount of discretion left to the investigator on how to approach a scientific problem."

It remains to be seen whether Barton will agree. He has called for the investigation as his committee considers a draft of a sweeping reauthorization bill, which would affect the NIH's basic organization.

Emma Marris

\section{Pioneering HIV treatment would use interference and gene therapy}

Scientists have unveiled plans to test an HIV treatment based on a much-touted technique that hasn't yetbeen tried on people.

The treatment is basedon a mechanism called RNA interference (RNAi), which can be used by cells toshut down invading viruses. Scientists and the biotechnology industry believe the interference pathway is a tremendously promising target for a variety of therapies. Two clinical trials of RNAi therapies have already begun, but the HIV proposal goes a step further, combining RNAiwith gene therapy. It will be a closely watched test of whether the field can fulfil

its potential.

Leaders of the trialdescribed their plans to the US Recombinant DNAAdvisory Committee (RAC) on 21 September. The committee gave generally favourable reviews, butrecommendedfurther safety tests before the study begins.

One of the trial's leaders is John Rossi, a molecular biologist at City of Hope's Beckman Research Institute in Duarte, California. Rossisays histeam willperform these extra tests before asking the Foodand Drug Administration (FDA) for approval to begin the trial.

If the FDAsays yes, Rossi and his team will test the therapy on five HIV patients whohave ablood cancer called lymphoma. They will treat the patients' lymphoma with aggressive chemotherapy and a bone-marrow transplant $-\mathbf{a}$ normal procedure. But before the transplant, they will use gene therapy to add stretches of DNA to stem cellsin the bone marrow. It is hoped that molecules encoded by the added genes will trigger the cells' RNAidefences against HIV.

The trial is different from the RNAitrials already under way, because the molecules used in those studies remain in the body for only a short time. The City of Hope researchers will deliver DNA packaged into a gene-therapy vector that could persist in patients for months or even years.

The RAC is cautious for that reason, and because the trial will set another precedent: it is the first in which researchers will use a lentivirus todeliver therapeutic genes to patients'stem cells. Lentiviruses are related to retroviruses, which were used in gene-therapy trials that caused cancer in three children with a rare immunodeficiency disease (see Nature 433, 561; 2005).

"We need to be careful, because now we have a study that's using a vector in the same family as the retrovirus, it's going into stem cells, and it's going into immunodeficient patients," says Diane Wara, who chairs the RAC.

The City of Hope team will monitor its patients to see whether the therapy causes cancerous mutations. The preliminary experiments are promising, Wara told Nature, emphasizing that she was speaking for herself, and not for the RAC. "John Rossi's work is beautifully done, and his data are very compelling."

Inter fering with HIV: a clinical trial of a combined treatment is under review.

GRAMMARANALYSIS 